\title{
COHESION AND COHERENCE: AN ANALYSIS OF THE STUDENTS' NARRATIVE
}

\section{WRITINGS}

\author{
Egi D. Putra ${ }^{1}$, Heri Samudra ${ }^{2}$, Ani Susanti ${ }^{3}$ \\ ${ }^{1,2,3}$ Universitas Ahmad Dahlan \\ Email: egidwiputra8@gmail.com
}

\begin{abstract}
The research was conducted to analyze cohesion and coherence used on 20 student's narrative writing in SMAN 4 Praya. Descriptive qualitative method used in this research by collecting data from students narrative writing assignments. Then, classifying the findings by using the theory introduced by Halliday and Hasan (1976). The results obtained from the data were: (a) grammatical cohesion; reference $61.09 \%$, substitution $13.53 \%$, ellipsis $04.88 \%$, and conjunction $26.50 \%$; 2) lexical cohesion; repetition $72 \%$, synonym $18 \%$, and collocation $10 \%$. (b) the students' produced coherence of the narratives; the development of themes and generic structure. The data shows that students were able to organize their ideas cohesively and coherently. It is evident that the students' writing ability was sufficiently developed by using cohesion and coherence devices.
\end{abstract}

Keywords: Cohesion, Coherence, Narrative

This work is licensed under Creative Commons Attribution License 4.0 CC-BY International license

\section{INTRODUCTION}

\subsection{Introduction}

English language subject is taught in school and to be the one of the subjects in the school that taught based on the curriculum of learning English (Depdiknas, 2005). There are four English language skills taught to students in the schools; reading, speaking, writing, and listening. Skill of writing is one of the important skills in learning English. Ahmad (2010:211) states that writing skill is an activity that requires enough time to think about the specific topic to analyze and classify any background of knowledge. Harmer (2004) also states that writing is a communication form to deliver feeling through written text.

There are some good writing characteristics (Sutama, 1979) the text should unity, coherence, and adequate development. The writing skill will help the students in communicating and sharing information to others. Olshtain (2001:207) views writing as a model of communication process between the writer and the reader. This skill is very important in the 
process of language learning. The people are able to express their feelings and thoughts with writing language skill (Akinwamide, 2018).

Another important aspect in creating good writing, the students should make the text cohesively and coherently. Coherence is the way to relate sentences group based on the context (Halliday and Hasan, 1976:23). Cohesion refers to how we combine the discourse. McCarthy (1991) emphasizes that the matter of cohesion and cohesive devices are of paramount importance for writing a readable text. (Hwang and Merrifield, 1992) also considers that coherence is very influential for creating a written text communicative and comprehensible to the readers. Therefore, cohesion and coherence are essentially required in a good composition of writing, and it directly affects its quality of writing.

Usually, the students will face difficulties in writing when English is not their first language. Some cases show that students have difficulties in creating a good writing. One of the text that students have difficult to write is a narrative. Narrative is written text that tell a story by connecting an events. (Kane, 2000) states that a narrative text are characterized by the existence time of events. (Sulistyo, 2013) views that the story in the narrative text is not always imaginative, but also factual based on the events or everyday experiences. There some categories of narrative; fiction, nonfiction, folklore/fable stories, fairy tales, and so on (Sarwani, 2015).

There have been a number of studies focusing on cohesion and coherence. The first research coming from Ayub (2013) shows that cohesive and coherent devices have to be concerned in teaching writing and the teachers have to be proficient in evaluating the coherence of students' writings by applying TPA. Another interesting research written by Ina N. H (2017) finds that the students have a good understanding in making cohesion and coherence aspects on their writing. Based on the information above, the researchers are interested in analyzing cohesion and coherence aspects of narrative writings written by the second grade of SMAN 4 Praya. The second graders should be able to produce narrative writing because they have been learning about narrative text.

\subsection{Research questions}

Regarding cohesion and coherence components in the student's writing projects, two questions are addressed to be explored, namely: (1) how are cohesion and coherence used in the student's writing on narrative texts? And (2) how is the level of their writing performance in terms of cohesion and coherence.

\subsection{Significance of the study}

Cohesion ad coherence aspects are very important thing in creating a good writing. This research will show the results of student narrative writing by using cohesion and coherence aspects. The findings of this study will directly benefit to students and teachers in doing writing class. The teachers can give more cohesion and coherence exercise to the students and students will understand the cohesion and coherence devices. 


\section{METHOD}

\subsection{Research Design}

In this study uses descriptive qualitative methods to analyze the types of cohesion and coherence on students' writing narrative text. In desriptive qualitative method, Descriptive method is one of the kind of research design to use descrivbe the phenomenon or fact about or research. In this study present, the researcher analyze the writing of students through tests after analyzing data, so the researcher describe the results of data.

\subsection{Samples/Participants}

Sampling is one of the improtant step that we carry out to collect data. Here there are many kinds of sampling in qualitative method such as convenience sampling, purposeive sampling, snowball sampling and theoretical sampling. In this research. The researcher took the data randomly from 20 second grades of senior high school in SMAN 4 Praya. The researcher choose 20 second grades because they had been learn about narrative text based on curriculum. They are qualified enough to take the narrative test given by the researchers.

\subsection{Instruments}

As we know that theere are many instrument that used in various study such as interview, questionnaire and so on. In this context, the researchers used a test as the instrument by asking them to write narrative text. Tests are one of systematyc procedure to meassure the behavior of participant (Sugiyono, 2011) states that the instrument is an important part of the research. The result of the test is students' narrative writing. Then, the researchers analyze the cohesion and cohesive devices on students' narrative writing.

\subsection{Data analysis}

There are some procedures in this research. Firstly, the researcher made sure that all of the students had learned about narrative text. Then, giving them a written test and asking them to make narrative text. The goal of this test is to find the types of cohesive and coherent devices on their narrative text. After they finished the test, the researcher collected their worksheet and analyzed the data to find cohesive and coherent devices. The first step that the researcher do to analyze data. The researcher analyze types of grammatical cohession such refrences, conjucntion, elipsis and subtitution.

As the example on students rwiring in narrative text. Once upon a time, there were two close friend who were walking through the forest together They knew that anything dangerous can happen anytime in the forest, so they promised each other.that they would always be together in any case of rdange. On students writing, the researcher analyze how many refrences, conjunction, elipsis, and subtitution that appear on students writing in narrative , after analyzing, the researcher give the point of types of grammatical cohession that appear on students writing.

\section{FINDINGS AND DISCUSSION}

\subsection{Findings}

In table 1, showing the result of the number cohesive devices on the students' narrative writing by using the theory introduced by Halliday and Hasan (1976) such as grammatical 
cohesion; reference, substitution, conjunction, ellipsis and lexical cohesion; repetition, synonym, and collocation. The result of the student's grammatical cohesion as follow:

Table 1. The Use of Grammatical Cohesion

\begin{tabular}{|c|c|c|c|}
\hline $\begin{array}{l}\text { Reference } \\
\text { (Writing 1-20) }\end{array}$ & $\begin{array}{l}\text { Substitution } \\
\text { (Writing 1-20) }\end{array}$ & $\begin{array}{ll}\text { Ellipsis } & \text { (Writing } \\
\text { 1-20) } & \\
\end{array}$ & $\begin{array}{l}\text { Conjunction } \\
\text { (Writing 1-20) }\end{array}$ \\
\hline 1.28 & $1 .-$ & 1. - & 1.15 \\
\hline 2. 6 & 2. - & 2. - & 2.7 \\
\hline 3.25 & 3. - & 3. - & 3. 10 \\
\hline 4. 14 & 4. - & 4. - & 4. 4 \\
\hline 5.7 & 5.1 & 5. - & 5.5 \\
\hline 6.4 & 6. - & 6. - & 6.2 \\
\hline 7.9 & 7. - & 7. - & 7. 8 \\
\hline 8.17 & 8. - & 8.3 & 8.19 \\
\hline 9.1 & 9. - & 9. - & 9.1 \\
\hline 10.1 & 10. - & 10. - & 10.1 \\
\hline 11.17 & 11. - & 11. - & 11.5 \\
\hline 12. 24 & 12. - & 12. - & 12. 10 \\
\hline 13.7 & 13. - & 13. - & 13. 10 \\
\hline 14. 10 & 14. 1 & 14. - & 14.5 \\
\hline 15.8 & 15. - & 15. - & 15.8 \\
\hline 16. 37 & 16. 18 & 16. 1 & 16. 1 \\
\hline 17. 16 & 17.8 & 17.4 & 17. - \\
\hline 18. 50 & 18.19 & 18.6 & 18.1 \\
\hline 19.26 & 19.15 & 19.3 & 19. 1 \\
\hline 20. 18 & 20.7 & 20.7 & 20.1 \\
\hline $\begin{array}{l}\text { Total: } \\
325(61.09 \%)\end{array}$ & Total: $72(13,53 \%)$ & Total: $26(04.88 \%)$ & Total: 141(26.50\%) \\
\hline
\end{tabular}

From the analysis above, it showed that students in SMAN 4 Praya have more awareness in creating cohesive devices. The students use all grammatical cohesion in their narrative writings. It means that the students have known these kinds of cohesive devices. For the results, 
the students used reference devices more frequently than other devices. The percentage of reference was the highest (61.09\%), followed by conjunction $(26.50 \%)$, substitution (13.53\%) and ellipsis (04.88\%).

Based on the narrative themes, the students' narrative writing is connected with the answers obtained from the worksheets. The students were interested in writing themes such as legends, fables, love, myth and experience. Thus, there was similarity between their narrative text and the worksheet. So, the data from the worksheet propped the findings on the students' narratives. The percentage of themes in the students' writings as follow:

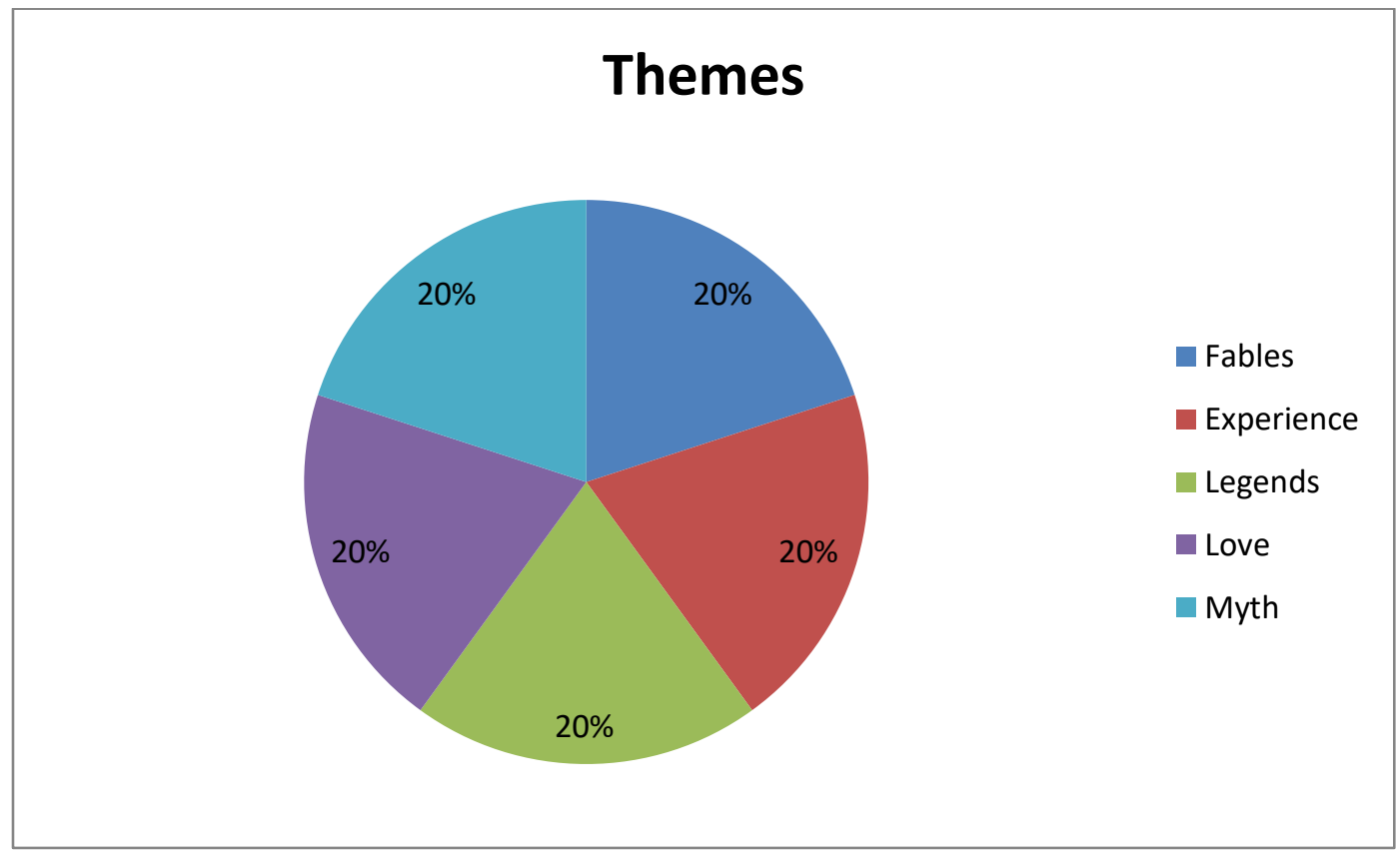

The students developed the theme. The story was developed by connecting the events, including orientation, complication and resolution. Related to the data, the students can explore the idea of the paragraph based on the theme that they like. It could be seen from the text arranging based on its generic structure. The result of generic structure presented below:

Table 2. The Generic Structure

\begin{tabular}{|c|l|c|ccc|}
\hline No & \multicolumn{2}{|c|}{ Titles } & \multirow{2}{*}{ Themes } & \multicolumn{4}{|c|}{ Generic Structure } \\
\cline { 4 - 6 } & & & O & C & R \\
\hline $\mathbf{1}$ & The Legend of Putri Mandalika & Legends & V & V & V \\
\hline $\mathbf{2}$ & True Friend & Experience & V & V & V \\
\hline $\mathbf{3}$ & The Story of Toba Lake & Legends & V & V & V \\
\hline $\mathbf{4}$ & A Donkey and A Lapdog & Fables & V & V & V \\
\hline $\mathbf{5}$ & My Trip My Advanture & Experience & V & V & V \\
\hline $\mathbf{6}$ & Snow White & Legends & V & V & V \\
\hline $\mathbf{7}$ & The Silent Love & Love & V & V & V \\
\hline
\end{tabular}




\begin{tabular}{|c|l|c|ccc|}
\hline $\mathbf{8}$ & Malin Kundang & Legends & V & V & V \\
\hline $\mathbf{9}$ & My Life was My Adventure & Experience & V & V & V \\
\hline $\mathbf{1 0}$ & The Lion and The Mouse & Fables & V & V & - \\
\hline $\mathbf{1 1}$ & My Holiday & Experience & V & - & V \\
\hline $\mathbf{1 2}$ & Dewi Sri & Myth & V & - & - \\
\hline $\mathbf{1 3}$ & Pinocchio & Myth & V & V & \\
\hline $\mathbf{1 4}$ & The Fox and The Grapes & Fables & V & V & V \\
\hline $\mathbf{1 5}$ & The Blind Girl & Love & V & V & V \\
\hline $\mathbf{1 6}$ & Falling in Love & Love & V & V & V \\
\hline $\mathbf{1 7}$ & Story of Becca and Joe & Fables & V & V \\
\hline $\mathbf{1 8}$ & Fox and A Cat & Myth & V \\
\hline $\mathbf{1 9}$ & Aji Saka and Dewata Cengkar & Myth & V & V & V \\
\hline $\mathbf{2 0}$ & Why Does the Sea Become Salty & & & & \\
\hline
\end{tabular}

\subsection{Discussion}

The present research that was conducted in SMAN 4 Praya aims to investigate the students' narrative writing. The second grade of senior high school was selected as the subject and the narrative writing was treated as the source of the data. Halliday and Hasan (1976) explained that cohesion was a factor that indicated whether a text was well connected or merely a group of unrelated sentences.

Based on the finding, the cohesion of the narratives was created through the use of cohesive devices. It showed that the second grade student in SMAN 4 Praya had more attention to the creation of cohesion. This could be seen from the number of used cohesive devices. Most of them are involved in two categories of cohesion were found the students' English narratives writings, those are: grammatical cohesion and lexical cohesion.

The first category includes the use of references, substitutions, ellipsis, and conjunctions. The second includes the use of repetition and collocation. The use of grammatical cohesion is found in all students' narrative writing. This shows that students already know the type of device.

For example, students use reference devices the most often compared to other devices because the highest percentage of references $(61.09 \%)$, followed by conjunction devices (26.50\%), substitution devices (13.53\%), ellipsis (04.88\%). Most of the findings revealed that they often combined the use of these cohesive devices when writing narrative texts. By relying on the cohesion theories in the previous chapter, knowledge of the cohesive device provides them in developing their writings.

Factors that might be thought to contribute to the highest percentage of references presented in this study include the nature of the narrative writing and the assignments used. Writing assignments require students to write down their personal experiences, legends, fairy tales, love and myths. Therefore, reference sets, especially personal reference items, are widely used in narrative writings because a story must be about a person, thing, or event. Therefore, after mentioning the person (either himself or someone), things or events in the story, it is often 
replaced with the personal reference "I, me, my / he, him, his / she, her, hers / it, it's / they, them" in the following sentences.

The students generally used the four types of conjunction much in their English narrative writing. They used the simplest form of each type frequently in their narratives writing: the conjunction 'and' for additive, 'but' for adversative, 'because/cause' for causal, and 'then/and then' for temporal conjunction. However, some of the students frequently used these conjunction items in a fairly confused way. For instance, they used an additive conjunction instead of an adversative one or the use temporal conjunction instead of additive one, i.e., they were not able to see the difference between them. This might be due to the insufficient practice inside the classroom, mainly in the area of conjunction.

In terms of the use of substitution, this kind of grammatical cohesion is the least used. This implies that the students are not used to this kind of cohesion. Because the occurrence is so low that the occurrence does not have much effect on the cohesion of the narrative. Table 4.1 shows that there are 72 substitutions $(13,53 \%)$ and 26 ellipsis $(04.88 \%)$ used by students in their narrative writing. Halliday and Hasan (1976) have stated that neither substitution nor ellipsis is rarely found in narratives or descriptions but is present in many examples of dialogue. In this study, students were confused between substitution and ellipsis because there was no clear line between the two.

In terms of lexical cohesion, this kind of cohesion occurred almost in all students' narratives. The category included reiteration and collocation. The reiteration included repetition, synonym or near synonym, superordinate, and general word. From the finding that repetition is the most familiar, then followed by collocation, synonym, superordinate, and general word. The occurrence of repetition was about 68 items or $(72 \%)$ of the total of lexical cohesion. This finding implied that the students still repeated the similar word or phrases to create cohesion in their narrative.

The coherence section was analyzed; (a) the narrative themes, (b) the paragraph idea and (c) the generic structure of the narrative text. Based on the result of data analysis, mostly the students' narrative writings were coherence. The themes that students are interested in give an impact on their narratives writing development. There were five themes used in the students' narratives such as fables 4 items (20\%), experience 4 items (20\%), legends 4 items (20\%), love 4 items $(20 \%)$, and myth 4 items $(20 \%)$. The themes support students' writing in creating the idea of each paragraph. This correlation gives a good impact on their writing progress

\section{CONCLUSIONS}

\subsection{Conclusion}

The goal of this research is to find the answer of formulated research questions, i.e. How are cohesion and coherence used in the student's writing on narrative texts and how is the level of their writing performance in terms of cohesion and coherence. With regard to the research findings, there are two conclusions made;

First, the students' grammatical cohesion performance was very good. In this case, the students were able to organize their ideas cohesively and coherently. It is evident that the students' writing ability was sufficiently developed by using grammatical cohesion. 
Second, most of the students used a narrative generic structure coherently. The significant effect on the themes that students find interesting help them to develop their narrative writing. However, students should still be given more opportunities to do more writing assignments, and English teachers should help students learn how to create cohesion and coherence in written text.

\subsection{Suggestions}

This article has shown the potential of cohesion and coherence aspects in improving students' writing. Therefore, it is suggested that teachers can design writing classes by providing the students more opportunities to learn more about cohesion and coherence devices. It is recommended that teachers and students use a variety of cohesion devices in creating writing tasks. This research is just focused on narrative writing tasks. Thus, future research on how cohesion and coherence aspects might be used by the students to write an academic essay.

\section{REFERENCES}

Ahmad, A. H. (2010). Students' Problems with Cohesion and Coherence in EFL Essay Writing in Egypt: Different Perspectives. Literacy Information and Computer Education Journal, Volume 1, issue 4. December 2010.

Akinwamide, T.K. (2018). Enhanced Collaborative Teaching Method on The Performance of Students in Essay Writing Task. Budapest International Research and Critics InstituteJournal, 1(3) 84-90.

Ayub, S. (2013). An analysis of the cohesion and coherence of students' English writings at the second grade of SMAN 1 Labuapi West Lombok. E-Journal Program Pascasarjana Universitas Pendidikan Ganesha.

Dinas Pendidikan dan Kebudayaan. (2005). Kurikulum 2004 Standar Kompetensi Mata Pelajaran Bahasa Inggris Sekolah Menengah Pertama: Jakarta.

Halliday, M. A. K., \& Hasan, R. (1976). Cohesion in English. London, UK: Longman Group Ltd.

Harmer, J. (2004). How to teach writing. England, UK: Pearson Education ESL.

Hasanah, I. N. (2017). A cohesion and coherence on students' exposition writing. Tugas Akhir Program sarjana. Universitas Islam Negeri Syarif Hidayatullah. Jakarta.

Hwang and William R. M. (1992). Language in context: Essays for Robert E. Longacre, 577-592. Dallas: Summer Institute of Linguistics and the University of Texas at Arlington.

Kane, T.S. (2000). The Oxford Essential Guide to Writing. New York: The Berkley Publishing Group.

McCarthy, Michael. (1991). Discourse Analysis for Language Teachers. Cambridge: Cambridge University Press. 
Olshtain, Elite. (2001). Functional Tasks for Mastering the Mechanics of Writing and Going Just Beyond. In Marianne Celce Murcia (Ed), Teaching English as a Second or Foreign Language (pp. 207-232). Thomson Learning. Inc: United States of America.

Sarwani, Ahmad. (2015). Narrative Text Sebagai Sumber Belajar Mata Pelajaran Bahasa Inggris untuk Menumbuhkan Nilai Moral Peserta Didik. Lingua, 12(2) 243-254.

Sugiyono. (2011). Metode penelitian pendidikan. Jakarta, DKI: Alfabeta.

Sulistyo, I. (2013). An Analysis of Generic Structure of Narrative Text Written by the Tenth Year Students of SMA Yasiha Gu. ETERNAL, 4(2) 169-181.

Sutama, I. (1979). Perkembangan Koherensi Tulisan Siswa Sekolah Dasar. Malang: Institut Keguruan dan Ilmu Pendidikan. 